\title{
THE CONCEPT OF HUMAN SECURITY BEFORE THE 1994 HUMAN DEVELOPMENT REPORT. INQUIRY INTO ITS EVOLUTION DURING THE COLD WAR
}

\author{
Alexandru Lucinescu ${ }^{1}$ \\ "Carol I" National Defence University
}

\begin{abstract}
It is usually considered that the concept of human security was introduced by the United Nations Development Programme with the publication in 1994 of the Human Development Report. Such a perspective on the emergence of this concept denies its existence during the Cold War and places its point of origin in the aftermath of that confrontation. However, there is also the opinion that human security was a term used during the Cold War, but that the meaning then attached to it lacks any relevancy for the meaning it has in the 1994 Human Development Report. This article contributes to the assessment of the viability of these different opinions by first exploring the use of the concept of human security by Niels Bohr in an open letter from 1950, and by Sithu U Thant, in a statement made in 1971, and secondly by comparing the meaning they gave to it with its meaning from the 1994 Human Development Report. It is concluded that both Bohr and $U$ Thant operated with a concept of human security narrower in scope than the concept of human security which is to be found in the 1994 Human Development Report and, based on this finding, that the evolution of this concept started long before 1994.
\end{abstract}

Keywords: human security; 1994 Human Development Report; Niels Bohr; Sithu U Thant; Cold War; United Nations Development Programme.

\section{INTRODUCTION}

The United Nations Development Program (UNDP) and the Pakistani economist Mahboub ul Haq, who served as Special Adviser of the UNDP Administrator from 1989 to 1996 and, in this capacity, initiated in 1990 the elaboration of the Human Development Report, including that from 1994, is considered to have played the leading role in theorizing human security, various authors equally giving them credit for introducing the term of human security. This article aims at considering the possibility for the term human security to be in use even before the publication of the 1994 Human Development Report, more exactly during the Cold War, and thus it calls into question the idea that it is this document which introduced the concept.

What prompted the investigation have been a remark by Diana Amnéus and an assertion by David Bosold. the remark made that human security was already employed in the 1960s in the field of psychology as proved by the publication in 1966 of the book entitled Human Security: Some Reflections authored by William Blatz (Amnéus 2013, 6), and the assertion of David Bosold who maintains that the introduction of the concept of human security by UNDP is simply a myth which ignores that this term figured in the open letter to the United Nations written in 1950 by the famous physicist Niels Bohr and in a statement made in 1971 by Sithu U Thant during his tenure as UN Secretary-General (Bosold 2011, 30). However, taking into account that the term human security employed by the UNDP belongs to the vocabulary of international security (Robinson, 2008, 96, 97), only the concept used by Bohr and $U$ Thant is relevant as an antecedent to the concept which figures in the 1994 Human Development Report. Despite maintaining that the concept of human security

\footnotetext{
${ }^{1}$ Corresponding author: alucinescu@gmail.com
} 
existed prior to the 1990s, Bosold does not analyze the meaning attributed to it by Bohr and U Thant because he considers that it has no relevancy for the meaning that UNDP latter attributed to it (Bosold 2011, 30).

Assuming that a critical approach to the genealogy of the concept of human security could advance the understanding of it, the first section of this article briefly reviews opinions in support of the idea that, back in 1994, UNDP introduced the term human security, and its second section examines what human security meant for Bohr and $U$ Thant and also compares the meaning attributed by them to human security with the meaning given to it in the 1994 Human Development Report.

\section{THE INTERPRETATION OF THE 1994 HUMAN DEVELOPMENT REPORT AS THE ORIGIN OF THE TERM HUMAN SECURITY}

As authors arguing that the term human security was created in 1994 with the publication of the Human Development Report elaborated by the UNDP, one could mention Amitav Acharya, Gerd Oberleitner, Wolfgang Benedek, Georg Frerk, Berma Klein Goldewijk, Caroline Thomas, S. Neil MacFarlane, Yuen Foong Khong, Christine Chinkin, Mary Kaldor and Šárka Waisová.

Amitav Acharya argues that 'the origin of the concept of human security can be traced to the publication of the Human Development Report of 1994, issued by the United Nations Development Programme (UNDP 1994)' (Acharia 2008, 492).

At his turn, Gerd Oberleitner considers that "human security as a distinctive new concept was created and shaped by Mahbub ul-Haq in and around the 1994 UNDP Development Report (Oberleitner 2005, 185) and Wolfgang Benedek is of the opinion that the concept of human security (...) in 2014 reached 20 years of age (...) In 1994, with the publication of the Human Development Report, the UNDP started its focus on the human person and launched the concept of human security" (Benedek 2016, 140).

Georg Frerks and Berma Klein Goldewijk maintain that 'UNDP's Human Development Report of 1994 catapulted the notion of human security into policy discourse and - looking back - the introduction of the concept can be considered a significant event in the academic and policy world (Georg Frerk, Berma Klein Goldewijk 2007, 26).

As for Neil S. MacFarlane and Yuen Foong Khong, they indicated that "the UNDP laid the concept of human security on the table" (MacFarlane, Khong 2006, 162), while Christine Chinkin and Mary Kaldor hold the view that "the story of human security usually starts with the UN Development Programme (UNDP) Human Development Report of 1994" which brought together various elements "under the umbrella of the term human security" (Chinkin, Kaldor 2017, 181).

Finally, Šárka Waisová considers that "The concept arose from the ashes of the Cold War during the debate about the new world order" and was "first presented by the UN Development Programme (UNDP) in its 1994 Human Development Report" (Šárka Waisová 2018, 80).

It follows that the idea of identifying the origin of the term human security with the publication of Human Development Report for 1994 is a well-established one within the academic field so that proving its inaccuracy entails significant consequences.

\section{THE CONCEPT OF HUMAN SECURITY AS DEFINED BY NIELS BOHR, SITHU U THANT, AND THE UNITED NATIONS DEVELOPMENT PROGRAMME}

Niels Bohr's open letter to the United Nations from 1950 is part of his efforts since 1944 to persuade policymakers to take the measures that he considered necessary for avoiding a nuclear arms race and a nuclear war. In early 1944, when Bohr and other physicists worked in the United States to build the first atomic bomb, Bohr realized the profound moral implications of the creation of this weapon and brought them to the attention of the Prime Minister of the United Kingdom, Winston Churchill, during a conversation with him that took place on 16 of May 1944 (Aaserud 2003, 307-309). The same reasons determined Bohr to equally present these implications to the President of the United States, Franklin D. Roosevelt, on the occasion of a meeting held on 26 of August 1944 and by 
means of two memoranda he sent to him on 3 of July 1944, and on 24 of March 1945 (Aaserud 2003, 307-309, Pais 1993, 517).

The reaction of the two politicians was not a favorable one, as they not only refused to follow the proposals put forward by Bohr, but even started to consider him as a potential danger for keeping the atomic bomb secret. This failure did not cause Bohr to renounce but determined him on 17 of May 1948 to address a memorandum to Harry Truman, Roosevelt's successor as President of the United States, an initiative which failed to persuade him to change the US policy on energy and nuclear weapons (S. G. Suvorov 1985, 935- 936).

In this open letter from 1950, Bohr resumed the most important passages from the two memoranda sent to Franklin D. Roosevelt and developed the ideas included therein (Bohr 1950). Bohr pointed out that atomic weapons pose a permanent threat to the existence of human civilization, of common security, of world security and of human security, but argued that this threat could be completely eliminated by establishing an international system for verifying the use of atomic energy to which all states should adhere (Bohr 1950, 6). According to Bohr, such a system involved building a climate of trust between states by ensuring absolutely free access to scientific and technical achievements in the nuclear field given that keeping secrecy about them, albeit considered by states that disposed of nuclear weapons to be indispensable for their own security, was, in fact, a major source of insecurity for them all (Bohr 1950, 4).

Bohr was of the opinion that the negotiations for the establishment of a system for verifying the use of atomic energy should have taken place within the United Nations because one of the objectives assumed by this organization was the cooperation between states in areas of common interest, and the scientifical field, in particular that of nuclear energy, was one of these areas (Bohr 1950, 5).

It is to be remarked that Bohr understood by human security the protection of people from the devastating effects of a nuclear war, which means that he conceived human security as the protection of any person against the physical violence represented by this type of interstate armed conflict. Given that he spoke about both international security and human security, one could maintain that he distinguished between the security of states and the security of their population. It follows that, considered from the point of view of the population of a state, the threat to human security that Bohr referred to originated from outside of that state, that is from another state. The fact that Bohr argued that the United Nations had to be entrusted with the coordination of the negotiations for establishing the cooperation and transparency in the nuclear field proves that he assigned to the United Nations a central role in providing human security.

As for the statement by Sithu U Thant, David Bosold cites the following passage: 'the massive sums devoted to armaments do not increase international or national or human security or happiness' (Bosold 2011, 30). U Thant expresses here the idea that war is a threat to human security, which means that human security means protection against physical violence, but he indicates a different mean for providing human security, namely the reduction of the nation budgets for armaments. It is to be remarked that the former UN Secretary-General differentiated between international security, national security and human security so that it is possible to maintain that he operated a distinction between the security of states and the security of their population. Considering the population of a given state, it could be said that $U$ Thant refers to a threat to its human security coming from outside that state under the form of an international armed conflict, be it conventional or nuclear.

According to the 1994 Human Development Report, human security refers to the security of people from within states, thus going beyond state security (national security), and it is made up from seven dimensions, each of them associated with specific threats (United Nations Development Programme 1994, 24-33). Thus, it was maintained therein that threats could endanger economic security, food security, health security, environmental security, personal security, community security and political security. This document indicates that many of these threats come from within states, some of them having national authorities as their source, while others, such as international wars as a category of armed conflicts distinct from internal wars, are threats which originate from outside states. 
International war as a threat to human security is included in the category of personal security where it is classified as a threat from other states (United Nations Development Programme 1994, 30).

\section{CONCLUSIONS}

The perspective on human security put forward by Niels Bohr and Sithu $U$ Thant are quite similar given that they connect human security with the population of each state, because they distinguish the security of states from human security, and because they consider international war as a threat to human security.

One could also observe that UNDP, similar to Bohr and $U$ Thant, operate a distinction between human security and state security, linking the former with the population of each state, and treat international war as a threat to human security. However, unlike Bohr and U Thant, UNDP considers international war as just one among many threats to human security so that it broadens the scope of human security.

It follows that the concept of human security used by both Bohr and $U$ Thant was narrow compared to the concept of human security employed in the 1994 Human Development Report but not irrelevant for this one. Consequently, it could be argued that Bohr and $U$ Thant operated with a concept that is part of the evolution of the concept of human security which, consequently, did not start with the 1994 Human Development Report but much earlier, this document representing only a landmark in that evolution.

The findings of this article indicate that it is possible to identify other examples of the use of the term human security before the publication of the 1994 Human Development Report, so that further research on its roots has to be undertaken.

\section{REFERENCES}

Aaserud, Finn. 2003. "Niels Bohr's Political Crusade during World War II." In Mathematics and War edited by Bernhelm Booß-Bavnbek and Jens Høyrup. Basel: Birkhäuser Verlog.

Acharya, Amitav. 2008. "Human Security." In The Globalization of World Politics: An Introduction to International Relations edited by John Baylis, Steve Smith, Patricia Owens. Oxford: Oxford University Press.

Benedek, Wolfgang. 2016. "The Role of the Human Security Perspective". In from Cold War to Cyber War. The Evolution of the International Law of Peace and Armed Conflict over the last 25 Years edited by Hans-Joachim Heintze and Pierre Thielbörger. Heidelberg: Springer.

Bohr, Niels. 1950. "Open Letter to the United Nations". Science, 112, no. 2897: 1-6.

Bosold, David. 2011. "Development of the Human Security Field: A Critical Examination" In Critical Perspectives on Human Security: Rethinking Emancipation and Power in International Relation edited by David Chandler and Nik Hynek. London. Routledge.

Chinkin, Christine, and Mary Kaldor. 2017. International Law and New Wars. Cambridge: Cambridge University Press.

Frerks, Georg, and Berma Klein Goldewijk. 2007. "Human Security: Mapping the Challenges." In Human Security and International Insecurity edited by Georg Frerks, Berma Klein Goldewijk. Wageningen: Wageningen Academic Publishers.

MacFarlane, Neil S., and Yuen Foong Khong (eds.). 2007. Human Security and the United Nations. A Critical History, Bloomington: Indiana University Press.

Oberleitner, Gerd. 2005. "Human Security: A Challenge to International Law?." Global Governance 11, no. 2: 185-203.

Pais, Abraham. 1991. Niels Bohr's Times, in Physics, Philosophy, and Polity. Oxford: Clarendon Press. 
Robinson, Paul. 2008. Dictionary of International Security. Cambridge: Polity Press.

United Nations Development Programme. 1994. Human Development Report. Oxford: Oxford University Press.

Suvorov, S. G. 1985. "On the Publication of Niels Bohr`s „Open Letter to the United Nations." Soviet Physics Uspekhi 28, no. 10: 935-36.

Waisová, Šárka. 2018. "Human Security: An Analysis of the Dissemination of an Idea in World Politics." Politics in Central Europe 14, no. 3: 75-99.

This article is essentially a part of the first research report that was elaborated in the framework of the Ph.D. programme in Security and Intelligence that I am involved in at the "Carol I" National Defence University. 